\title{
ANALISIS SISTEM DAN PROSEDUR PEMBERIAN PEMBIAYAAN UMKMK PADA PT. PNM VENTURE SYARIAH MAKASSAR
}

\author{
Nur Fadny Yuliani \\ Dosen Politeknik Nasional, Makassar
}

\begin{abstract}
ABSTRAK
Penelitian ini merupakan penelitian deskriptif kualitatif, yang sifatnya menggambarkan tentang sistem dan prosedur, serta manfaat dari pemberian pembiayaan pada usaha mikro kecil, menengah, dan koperasi (UMKMK) pada PT. PNM Venture Syariah Makassar.Teknik pengumpulan data dilaksanakan dengan menyebar kuesioner, melakukan wawancara terhadap pihak-pihak yang terkait dalam pemberian pembiayaan terhadap UMKMK, dan melakukan obervasi.Teknik analisis data mengunakan analisis deskriptif kualitatif yaitu penggambaran dalam makna berdasarkan hasil wawancara, kuesioner, dan observasi.Hasil penelitian menunjukkan bahwa dari hasil tebar kuesioner yang dilakukan. Responden yang menyatakan setuju, cukup setuju dan sangat setuju sekitar 94 persen bahwa sistem pembiayaan UMKMK pada PT. PNM Venture Syariah Makassar memiliki manfaat terhadap nasabahnya, sedangkan sisanya yang menyatakan kurang setuju dan tidak setuju 6 persen. Sedangkan responden yang menyatakan setuju, cukup setuju dan sangat setuju sekitar 90 persen bahwa prosedur pembiayaan UMKMK pada PT. PNM Venture Syariah Makassar memiliki manfaat terbanyak sedangkan sisanya yang menyatakan kurang setuju dan tidak setuju sekitar 10 persen. Hal ini berarti bahwa sistem dan prosedur pembiayaan UMKMK pada PT. PNM Venture Syariah Makassar memiliki manfaat yang besar bagi kelangsungan usaha nasabahnya.
\end{abstract}

Kata Kunci: Sistem pembiayaan, Prosedur pembiayaan, UMKMK

\section{PENDAHULUAN}

Pembangunan ekonomi nasional Indonesia ditekankan pada pemerataan, salah satu dari jalur pemerataan itu adalah pemerataan kesempatan berusaha yang diberikan untuk Usaha Mikro, Kecil, Menengah, dan Koperasi (UMKMK). Pengembangan UMKMK yang merupakan ranah ekonomi kerakyatan menjadi sangat relevan dilakukan di daerah-daerah di Indonesia mengingat struktur usaha yang berkembang selama ini bertumpu pada keberadaan industri kecil/rumah tangga/menengah. Menurut Mubyarto bahwa "Ekonomi Rakyat" adalah sektor sektor ekonomi yang dihuni oleh pelaku ekonomi yang berukuran kecil. Sektor-sektor itu diantaranya UMKMK, KUD, sektor pertanian rakyat, sektor perikanan rakyat, sektor transportasi rakyat, termasuk perkreditan rakyat.

Perkembangan UMKMK juga terlihat dari hasil penelitian Renaldi (2010) yang menunjukkan bahwa jumlah UMKMK tahun 2009, sebanyak 48,9 juta unit usaha atau merupakan 99,99\% dari total unit usaha yang ada di Indonesia. Sedangkan kontribusi UMKMK 
60|Ad'ministrare, Vol. 3 No. 2, 2016

pada penyerapan tenaga kerja mencapai 85 juta, 96,18\%, dan kontribusi terhadap Produk Domestik Bruto (PDB) mencapai 53,28\%. Dari seluruh UMKMK itu, sampai saat ini yang telah mendapat bantuan dana dari perbankan 39,08\% atau 19,1 juta, sedangkan sisanya dianggap belum bankable. Melihat jumlah UMKMK yang begitu mendominasi sektor usaha swasta di Indonesia, maka tidaklah berlebihan jika UMKMK merupakan benteng pertahanan ekonomi nasional.

Dengan demikian sektor UMKMK sebagai pelaku ekonomi yang memberi andil cukup besar dalam denyut nadi kehidupan masyarakat yang memiliki fungsi dan peranan yang sangat penting, karena sektor tersebut tidak hanya sebagai sumber mata pencaharian orang banyak, tetapi juga menyediakan langsung lapangan kerja bagi mereka yang tingkat pengetahuan dan keterampilannya rendah.

Untuk mendorong pertumbuhan UMKMK diperlukan intervensi dari pemerintah, yaitu sesuai dengan Peraturan Pemerintah RI No.38/1999 Tanggal 29 Mei 1999, beberapa Bulan kemudian, melalui Kep Menkeu No. 487 KMK 017 Tanggal 15 Oktober 1999, sebagai pelaksanaan dari Undang-Undang No.23 Tahun 1999, PNM Venture Syariah ditunjuk menjadi salah satu BUMN yang menjadi koordinator untuk menyalurkan dan mengelola 12 skim program pembiayaan.

Pemberian pembiayaan merupakan kegiatan utama PNM yang mengandung risiko yang dapat berpengaruh pada kesehatan dan kelangsungan usaha PNM Venture Syariah.Maka pemberian pembiayaan banyak dibatasi oleh ketentuan undang-undang dan ketentuan OJK (Otoritas Jasa Keuangan).Pembiayaan dapat diperoleh baik dari PNM konvensional maupun PNM syariah. Pembiayaan merupakan salah satu cara bagi PNM untuk media penyaluran dana kepada masyarakat. Seperti diketahui, bahwa sumber dana PNM yang digunakan untuk disalurkan sebagai pembiayaan berasal dari APBN. Dengan melihat laporan keuangan yang akan menjadi nasabahnya, PNM dapat melakukan penilaian terhadap kondisi keuangan suatu perusahaan, apakah dalam keadaan baik atau buruk, dan apakah layak untuk mendapatkan pembiayaan atau tidak. Dalam menganalisis laporan keuangan perusahaan, analisis rasio merupakan salah satu analisis yang dapat digunakan. Rasio keuangan dapat menggambarkan pertumbuhan keuangan perusahaan dari tahun ke tahun, kemudian dapat melakukan perbandingan mengenai kondisi keuangan setiap tahunnya yang akan berhubungan dengan pengambilan keputusan pemberian pembiayaan. Selain memperhatikan dan melakukan penilaian terhadap laporan keuangan calon nasabahnya, pihak PNM juga harus memperhatikan prinsip 5C dari calon nasabah tersebut.Prinsip 5C tersebut adalah Character, Capital, Collateral, Capacity, dan Condition of Economy.Kelima prinsip tersebut sangat penting untuk menjadi penilaian sebelum memberikan persetujuan pemberian pembiayaan.

PNM Venture Syariah yang diberikan tugas pemberdayaan tersebut dilakukan melalui penyelengaraan jasa pembiayaan dan jasa manajemen, sebagai bagian dari penerapan strategi pemerintah untuk memajukan UMKMK, khususnya merupakan kontribusi terhadap sektor riil, guna menunjang pertumbuhan pengusaha-pengusaha baru yang mempunyai prospek usaha dan mampu menciptakan lapangan kerja.

Jika sistem dan prosedur pemberian pembiayaan sudah diterapkan dengan baik, mulai dari nasabah mengajukan permohonan sampai pelunasan, maka pihak PNM akan selalu dapat 
mengetahui dengan baik kegiatan dan perkembangan usaha nasabahnya. Sehingga jika persoalan yang dihadapi nasabah akan segera mengetahui dan berusaha membantu untuk kepentingan PNM sendiri. Pengawasan pembiayaan juga mutlak dilaksanakan untuk menghindari pembiayaan macet. Kondisi pembiayaan macet akan terlihat dari Non Performing Loan (NPL) atau tingkat pengembalian pembiayaan yang lebih dari 3\% yang merupakan batas toleransi pembiayaan yang tidak tertagih setelah dinyatakan macet, standar ini ditetapkan oleh OJK (Otoritas Jasa Keuangan) selaku pemegang otoritas pengaturan PT.PNM Venture Syariah di Indonesia. Non performing loan (NPL) sangat menentukan dalam penilaian tingkat kesehatan PT.PNM Venture Syariah yang memiliki nilai NPL lebih dari 3\% bisa dikategorikan tidak sehat.

PT.PNM Venture Syariah Perlu meminimalkan potensi kerugian yang akan muncul dikarenakan adanya pembiayaan macet tersebut, salah satunya dengan mengoptimalkan kebijakan-kebijakan PNM dalam hal pembiayaan yang tertuang dalam standar operasional Perusahaan dan dilakukannya pengawasan dalam hal pemberian pembiayaan.

Sebelum memberikandana, seorang Pimpinan atau Pejabat yang berwenang dalam memutuskan pemberian pembiayaan harus memperhatikan beberapa syarat sebagai dasar pertimbangan dalam memberikan pembiayaan seperti: siapa yang menginginkan pembiayaan, untuk apa pembiayaan digunakan, apa dan berapa nilai agunannya, dan bagaimana dan berapa lama pembiayaan akan dikembalikan kepada Bank dan beberapa pertimbangan lainnya yang diperoleh. Pengawasan pemberian pembiayaan adalah usaha yang produktif artinya pembiayaan itu dapat ditarik kembali bersama sesuai perjanjian yang telah disetujui oleh kedua belah pihak.Hal ini penting jika pembiayaan macet berarti kerugian bagi PNM bersangkutan.

Pembiayaan merupakan suatu proses yang membutuhkan pertimbangan analisis yang baik dari Pimpinan PT.PNM Venture Syariah. Jaminan atas $\mathrm{p}$ e $\mathrm{m}$ b i a y a a $\mathrm{n}$ yang dipinjam oleh nasabah sering menjadimasalah. Kemungkinan kerugian yang diderita PNM sebagian akibat nasabah tidak memenuhi kewajibannya sesuai dengan perjanjian yang telah disepakati.Pertimbangan analisis tersebut sangat dipengaruhi oleh ketentuan dan kebijaksanaan dari kantor pusat PT. PNM Venture Syariah itu sendiri. Pada dasarnya sebelum memberikan pembiayaan seorang Pimpinan diberi wewenang untuk memutuskan penyaluran pembiayaan, dengan memperhatikan beberapa hal sebagai bahan pertimbangan.Faktor-faktor tersebut sepertibesarnya jumlah dana yang diminta, tujuan penggunaan pembiayaan, kelayakan usaha calon nasabah, bentuk dan nilai jaminan yang diberikan serta beberapa pertimbangan lainnya yang diperlukan.

PT. PNM Venture Syariah Cabang Makassar didirikan pada Tanggal 1 Juni 1999, sebagai BUMN yang mengemban tugas khusus memberdayakan usaha Mikro, Kecil, Menengah, dan Koperasi (UMKMK).Yang sebagian sahamnya dimilki Berdasarkan Syariah, memberikan layanan jasa modal usaha diwilayah Makassar.Berbagai jasa pelayanan pemberian modal usaha telah dilaksanakan oleh PT. PNM Venture Syariah dalam upaya peningkatan kualitas, termasuk di dalamnya penyaluran pembiayaan.Adapun jenis-jenis pembiayaan tersebut antara lain, pembiayaan perdagangan, pembiayaan pertanian, pembiayaan investasi, pembiayaan modal kerja dan lain sebagainya.Setelah Sebelas Tahun beroperasi, seiring dengan meningkatnya kepercayaan masyarakat dan dunia usaha kepada perusahaan.Hingga kini, perusahaan tetap 
$62 \mid$ Ad'ministrare, Vol. 3 No. 2, 2016

fokus menyalurkan pembiayaan UMKMK kepada masyarakat yang hasilnya dinikmati oleh lebih dari Satu Juta Kepala Keluarga dan 1.500 Lembaga Keuangan Mikro di seluruh penjuru tanah air.

Namun demikian Pengawasan terus dilakukan oleh PT. PNM Venture Syariah Cabang Makassar yang merupakan hal penting dalam usaha perbankan, tujuan dari pengawasan pemberian pembiayaan ini untuk menjaga, mengamankan dan mengantisipasi terjadinya penyimpangan yang dapat menjadikan pembiayaan bermasalah dan jika tidak ditindaklanjuti akan menyebabkan kerugian bagi PNM.Serta dengan adanya sistem ini, pihak PNM dapat mengetahui dengan cepat munculnya potensi pembiayaan bermasalah yang dapat merugikan PNM.

\section{KAJIAN TEORI}

\section{Pengertian Pembiayaan}

Istilah pembiayaan sebenarnya memiliki bermacam-macam makna.Istilah ini secara akuntansi mungkin tidak seratus persen sama dengan yang dipahami orang awam. Istilah pembiayaan yang dimaksud dalam hal ini adalah pendanaan yang dilakukan oleh lembaga pembiayaan seperti bank syariah kepada nasabah. Pembiayaan secara luas berarti financing atau pembelanjaan yaitu pendanaan yang dikeluarkan untuk mendukung investasi yang telah direncanakan, baik dilakukan sendiri maupun dikerjakan oleh orang lain.

Menurut M. Syafi'I Antonio (2001) menjelaskan bahwa pembiayaan merupakan salah satu tugas pokok bank yaitu pemberian fasilitas dana untuk memenuhi kebutuhan pihak-pihak yang merupakan deficit unit.

Berdasarkan Undang-Undang Nomor 10 Tahun 1998 tentang perubahan atas UU Nomor 7 Tahun 1992 tentang Pembiayaan berdasarkan prinsip syariah adalah penyediaan uang atau tagihan yang dipersamakan dengan itu berdasarkan persetujuan atau kesepakatan antara bank dengan pihak lain yang mewajibkan pihak yang dibiayai untuk mengembalikan uang atau tagihan tersebut setelah jangka waktu tertentu dengan imbalan atau bagi hasil.

\section{Pembiayaan Usaha Nasabah Dengan Prinsip Syariah.}

Menurut Tulus Tambunan (2012:11) ada beberapa point penting pembiayaan usaha nasabah dengan prinsip syariah:

Lazimnya ada tiga prinsip syariah dalam melakukan akad pada bank syariah:

a Al-Mudharabah (Trust Financing, Trust Investement).

Al-Mudharabah adalah sistem kerja sama usaha antara dua pihak atau lebih di mana pihak pertama (shahib al-mal) menyediakan seluruh (100\%) kebutuhan modal (sebagai penyuntik sejumlah dana sesuai kebutuhan pembiayaan suatu proyek), sedangkan nasabah sebagai pengelola (mudharib) mengajukan permohonan pembiayaan dan untuk ini nasabah sebagai pengelola (mudharib) menyediakan keahliannya. Transaksi jenis ini biasanya 
mensyaratakan adanya wakil shahib al-mal dalam manajemen proyek.Mudharib sebagai pengelola yang dipercaya harus bertanggung jawab bila terjadi kerugian yang diakibatkan karena kelalaian dan wakil shahib al-mal harus mengelola modal secara profesional untuk mendapatkan laba yang optimal.Keuntungan usaha secara al-mudharabah dibagi menurut kesepakatan yang dituangkan dalam kontrak, sedangkan apabila rugi ditanggung oleh pemilik modal (bank) selama kerugian itu bukan akibat kelalaian di pengelola (nasabah).Selanjutnya bilamana kerugian tersebut sebagai akibat kecurangan atau kelalaian pengelola (nasabah), pengelola harus bertanggung jawab atas kerugian tersebut.Pada dasarnya kedua belah pihak kemudian berbagi hasil atas keuntungan usaha yang diperoleh. Dalam posisi ini bank berperan sebagai penyedia modal dan nasabah yang mengajukan permohonan pembiayaan yang akan menjadi pengelola dari usaha tersebut.

Landasan syariah dari al-mudharabah ini lebih mencerminkan agar setiap umat dianjurkan untuk melakukan usaha, seperti yang tertulis dalam Al-Quran dan Hadits. Pada sisi pembiayaan al- mudharabah umumnya diterapkan untuk pembiayaan modal kerja, seperti modal kerja perdagangan dan jasa, investasi khusus, yang disebut juga dengan mudharabah muqayyadah, di mana sumber dana khusus dengan penyaluran yang khusus dengan syarat-syarat yang telah diterapkan oleh bank sebagai penyandang dana.

Hal- hal yang perlu diperhatikan pada pembiayaan mudharabah agar semua bertanggung jawab dengan keputusannya masing-masing antara lain sebagai berikut:

1) Setiap penyerahan modal dari bank kepada pengelola harus jelas syarat dan waktunya.

2) Hasil usaha dibagi sesuai dengan kesepakatan yang tertera dalam akad.

3) Bank selaku pemilik dana berhak melalukan pengawasan, tetapi tidak ikut campur dalam usaha nasabah.

4) Hasil yang diperoleh dari pengelolaan modal dapat menggunakan perhitungan sebagai berikut:

- Berdasarkan perhitungan pada revenue sharing.

- Berdasarkan perhitungan pada profit sharing.

Keuntungan pembiayaan dengan al-mudharabah antara lain dapat dikemukakan sebagai berikut:

1) Bank akan memperoleh peningkatan bagian hasil tatkala keuntungan usaha nasabah meningkat.

2) Pengembalian pokok pinjaman diselaraskan dengan cash flow usaha nasabah sehingga tidak mengganggu bisnis nasabah.

3) Bank lebih selektif dan hati-hati dalam mencari jenis usaha dan nasabah yang benar-benar halal, aman, menguntungkan karena hasil keuntungan itulah yang akan dibagikan.

4) Prinsip bagi hasil ini berbeda dengan prinsip bunga yang diterapkan dalam bank konvensional (bunga tetap), di mana bank akan menagih nasabah untuk suatu jumlah bunga tetap berapa pun keuntungan yang dihasilkan nasabah, sekalipun nasabah menderita rugi akibat terjadi krisis ekonomi.

Kemungkinan risiko dalam al mudharabah, antara lain: 
64|Ad'ministrare, Vol. 3 No. 2, 2016

1) Penyalahgunaan dana yang diperoleh nasabah untuk keperluan/tujuan lain yang menyimpang dari kesepakatan semula.

2) Nasabah melakukan kesalahan yang disengaja, atau kelalaian yang tidak disengaja.

3) Nasabah yang tidak jujur menyampaikan perkembangan bisnis/usaha perusahaan.

\section{b Musyarakah (Partnership, Project Financing Participation).}

Karakteristik transaksi ini dilandasi oleh adanya keinginan dari para pihak (dua pihak atau lebih) melakukan kerja sama untuk suatu usaha tertentu. Masing-masing pihak menyertakan dan menyetorkan modalnya (baik intangible asset maupun tangible asset) dengan pembagian keuntungan di kemudian hari sesuai kesepakatan. Kepesertaan masingmasing pihak yang melakukan kerja sama dapat berupa dana (funding), keahlian (skill), Kepemilikan (property), peralatan (equipment), barang perdagangan (trading asset), atau intaqible asset seperti good will atau hak paten, reputasi/nama baik, kepercayaan, serta barang-barang lain yang dapat dinilai dengan uang. Bank syariah menyediakan fasilitas pembiayaan dengan cara menyuntikkan modal berupa dana segar agar usaha nasabah dapat berkembang kearah yang lebih baik.

Hal-hal yang perlu diperhatikan pada pembiayaan musyarakah agar semua bertanggung jawab dengan keputusannya masing-masing, antara lain sebagai berikut :

1) Semua modal (intagible dan tangible asset) disatukan sebagai modal usaha dan dikelola bersama. Setiap pemilik modal mempunyai hak turut serta (sesuai dengan porsinya) dalam menetapkan kebijakan usaha yang dijalankan oleh pengelola proyek (nasabah).

2) Adanya transparansi dan diketahui para pihak terhadap biaya yang timbul dalam pelaksanaan proyek serta jangka waktu proyek.

3) Keuntungan usaha dibagi sesuai kesepakatan, sedangkan kemungkinan rugi dibagi sesuai dengan porsi modal masing-masing.

4) Setelah pekerjaan (proyek) selesai, modal dikembalikan pada masing-masing pihak beserta sejumlah bagi hasil.

5) Akad hendaknya dibuat selengkap mungkin sehingga menghindarkan risiko yang tidak diinginkan di kemudian hari.

berikut:

Beberapa manfaat dari pembiayaan secara al-musyarakah antara lain sebagai

1) Bank akan memperoleh keuntungan berupa peningkatan dalam jumlah tertentu saat keuntungan usaha nasabah meningkat.

2) Pengembalian pokok pinjaman disesuaikan dengan cash flow usaha nasabah sehingga tidak memberatkan nasabah.

3) Bank lebih selektif dan hati-hati (prudent) dalam mencari jenis usaha yang benar-benar halal, aman, dan menguntungkan karena hanya keuntungan yang rill dan benar-benar terjadi yang akan dibagikan. 


\section{c. Prinsip bagi hasil dalam mudharabah/musyarakah.}

Berbeda dengan prinsip bunga tetap yang digunakan oleh bank konvensional, dimana bank akan menagih penerima pembiayaan nasabah untuk suatu jumlah bunga tetap berapa pun keuntungan yang dihasilkan nasabah. Bahkan meskipun nasabah menderita rugi akibat krisis moneter. Al-muzara'ah adalah kerja sama pengolahan pertanian antara pemilik lahan dan penggarap, dimana pemilik lahan memberikan lahan pertanian kepada penggarap untuk ditanami dan dipelihara dengan imbalan bagian tertentu (persentase) dari hasil panen.

\section{d Al-Musaqah}

Al-Musaqah ini merupakan bentuk yang lebih sederhana dari Al-muzara'ah di mana penggarap tanah hanya bertanggung jawab atas penyiraman dan pemeliharaan dan sebagai kompensasi atau imbalannya, penggarap memperoleh nisbah tertentu dari hasil panen.

\section{Definisi UMKMK}

Menurut Tulus Tambunan (2012:1) UMKMK adalah unit usaha produktif yang berdiri sendiri, yang dilakukan oleh orang perorangan atau badan usaha di semua sektor ekonomi. Sedangkan menurut Undang-Undang Republik Indonesia Nomor 20 Tahun 2008 tentang UMKMK dalam Bab 1 (Ketentuan Umum), Pasal 1 dari UU tersebut, dinyatakan bahwa UMI adalah usaha produktif milik orang perorangan yang memenuhi kriteria UMI sebagaimana diatur dalam UU tersebut. UK adalah usaha ekonomi produktif yang berdiri sendiri, yang dilakukan oleh orang perorangan atau badan usaha yang bukan merupakan anak perusahaan atau bukan cabang perusahaan yang dimiliki, dikuasai, atau menjadi bagian baik langsung maupun tidak langsung dari UM atau UB yang memenuhi kriteria UK sebagaimana dimaksud dalam undang-undang tersebut. Sedangkan UM adalah usaha ekonomi produktif yang berdiri sendiri, yang dilakukan oleh orang perorangan atau badan usaha yang bukan merupakan anak perusahaan atau bukan cabang perusahaan yang dimiliki, dikuasai, atau menjadi bagian baik langsung maupun tidak langsung dari UMI, UK, UB yang memenuhi kriteria UM sebagaiman dimaksud dalam UU tersebut.

Jadi di dalam UU tersebut, kriteria yang digunakan untuk mendefinisikan UMKMK seperti yang tercantum dalam Pasal 6 adalah nilai kekayaan bersih atau nilai asset, tidak termasuk tanah dan bangunan tempat usaha, atau hasil penjualan tahunan.

\section{METODE PENELITIAN}

\section{Jenis dan Lokasi Penelitian}

Berdasarkan jenis data yang akan dianalisis, maka jenis penelitian ini adalah penelitian deskriptif kualitatif karena penelitian ini bertujuan untuk menelusuri sistem dan prosedur 
66|Ad'ministrare, Vol. 3 No. 2, 2016

pemberian pembiayaan UMKMK pada PT. PNM Venture Syariah Makassar. Maka peneliti memilih salah satu perusahaan di KotaMakassar tepatnya pada PT. PNM Venture Syariah Makassar yang terletak di jalan Racing Centre No. 14 Makassar. Adapun yang akan dianalisis adalah sistem dan prosedur pemberian pembiayaan UMKMK pada PT. PNM Venture Syariah Makassar.

\section{Variabel Penelitian}

Variabel merupakan indikator terpenting dalam menentukan keberhasilan penelitian sebab variabel penelitian adalah objek yang menjadi titik perhatian dalam suatu penelitian. Menurut Ridwan dan Sunarto (2009:8) bahwa "Variabel adalah karakteristik yang dapat diamati dari sesuatu (obyek) dan mampu memberikan bermacam-macam nilai atau kategori".

Secara umum ada dua jenis variabel yang dapat digunakan dalam suatu penelitian.Kedua variabel tersebut adalah variabel bebas dan variabel terikat. Dalam penelitian ini yang menjadi variabel adalah sebagai berikut:

a) Sistem dan prosedur sebagai variabel bebas (X) merupakan variabel yang mempengaruhi variabel terikat.

b) Pembiayan UMKMK sebagai variabel terikat (Y) merupakan variabel yang dipengaruhi.

3.2 DeskriptifKonsep

Untuk memperjelas ruang lingkup penelitian maka dikemukakan deskriptif konsep agar tidak terjadi kekeliruan dalam mendefinisikan makna :

1. Sistem adalah Bagian-bagian dan sub bagian yang bekerja secara terkait dan terpadu dalam proses pemberian pembiayaan kepada UMKMK.

2. Prosedur adalah rangkaian aktivitas (kegiatan) yang berurut dan tidak saling melampaui di dalam proses pemberian pembiayaan pada UMKMK yang menjadi nasabahnya.

3. Manfaat sistem dan prosedur dalam pemberian pembiayaan adalah nilai guna dan manfaat yang dapat dirasakan dan dinikmati oleh UMKMK atas pemberian pembiayaan, berupa antara lain pemberian pembiayaan untuk usaha perdagangan, jasa, rumah tangga, dan perkebunan, dan lain -lain.

4. Usaha Mikro, Kecil, Menengah, dan Koperasi (UMKMK) adalah unit usaha produktif yang berdiri sendiri, yang di lakukan oleh orang perorangan atau badan usaha di semua sektor ekonomi.

\section{HASIL DAN PEMBAHASAN}

Manfaat Pemberian Pembiayaan Terhadap Usaha, Mikro, Kecil, Menengah, dan Koperasi (UMKMK). Untuk menganalisis manfaat sistem dan prosedur pemberian pembiayaan terhadap UMKMK, maka diberikan kuesioner terhadap 50 UMKMK yang diambil secara acak untuk menjadi responden. 


\section{Karakteristik Responden.}

Pada bagian ini akan dijelaskan mengenai data-data deskriptif yangdiperoleh dari responden. Data deskriptif penelitian disajikan agar dapat dilihat profil dari data penelitian dan hubungan yang ada antar variabel yang digunakan dalam penelitian. Data deskriptif yang menggambarkan keadaan responden sebagai informasi tambahan untuk memahami hasil-hasil penelitian. Adapun responden dalam penelitian ini berjumlah 50 nasabahUMKMK yang diambil secara acak dari PT. PNM Venture Syariah Makassar. 50 nasabah UMKMK yang menjadi responden yang berpartisipsi dalam penelitian ini dirinci berdasarkanlamanya usaha serta alasan menjadi nasabah pada PT. PNM Venture Syariah Makassar.

\section{Pembahasan}

a. Hasil Tabulasi Responden.

Penelitian yang telah dilakukan terhadap manfaat sistem dan prosedur pembiayaan Usaha Mikro, Kecil, Menengah, dan Koperasi (UMKMK).Menurut olah data yang telah dilakukan berdasarkan hasil pengamatan, wawancara dan tebar kuesioner dapat digambarkan tentang keinginan responden dalam menjawab setiap pertanyaaan yang diberikan oleh peneliti. Penelitian mengenai manfaat sistem dan prosedur pembiayaan UMKMK pada PT. PNM Venture Syariah Makassar, yaitu sebagai berikut:

1. Sistem pembiayaan Usaha Mikro, Kecil, Menengah, dan Koperasi (UMKMK).

sistem pembiayaan Usaha Mikro, Kecil, Menengah, dan Koperasi (UMKMK ) merupakan bagian-bagian dan sub bagian yang bekerja secara terkait dan terpadu dalam proses pemberian pembiayaan kepada UMKMK.

Komposisi Persentasi responden berdasarkan dari Item pertanyaan dari manfaat systempembiayaan ( Contoh pertanyaan terlampir) dapat dilihat pada tabel berikut:

Tabel 1. Distribusi Responden berdasarkan manfaat sistem pembiayaan

\begin{tabular}{|llll|}
\hline $\begin{array}{l}\text { No } \\
\text { Item }\end{array}$ & Tanggapan & $\begin{array}{l}\text { Jumlah } \\
\text { responden }\end{array}$ & Persentase \\
\hline 1 & Tidak Setuju ( TS) & 1 & $2 \%$ \\
2 & Kurang Setuju ( KS) & 2 & $4 \%$ \\
3 & Cukup Setuju ( CS) & 5 & $10 \%$ \\
4 & Setuju ( S ) & 33 & $66 \%$ \\
5 & Sangat Setuju ( SS) & 9 & $18 \%$ \\
\hline Jumlah & & 50 & $100 \%$ \\
\hline
\end{tabular}

Sumber: data telah diolah 
68|Ad'ministrare, Vol. 3 No. 2, 2016

Berdasarkan tabel 1 menunjukkan jumlah nasabah usaha mikro, kecil, menengah, dan koperasi (UMKMK) yang menyatakan sistem pembiayaan UMKMK memiliki manfaat usaha pada PT. PNM Venture Syariah Makassar berdasarkan hasil tebar kuesioner kepada nasabah dapat dilihat bahwa sekitar 2 persen nasabah yang menyatakan tidak setuju jika sistem pembiayaan UMKMK pada PT. PNM Venture Syariah Makassar memiliki manfaat, 4 persen yang menyatakan kurang setuju jika sistem pembiayaan UMKMK pada PT. PNM Venture Syariah Makassar memiliki manfaat, 10 persen yang menyatakan cukup setuju jika sistem pembiayaan UMKMK pada PT. PNM Venture Syariah Makassar memiliki manfaat, 66 persen yang menyatakan setuju yang jika sistem pembiayaan UMKMK pada PT. PNM Venture Syariah Makassar memiliki manfaat dan 18 persen yang menyatakan sangat setuju jika sistem pembiayaan UMKMK pada PT. PNM Venture Syariah Makassar memiliki manfaat jadi dapat disimpulkan responden yang menyatakan setuju,cukup setuju dan sangat setuju sekitar 94 persen sistem pembiayaan UMKMK pada PT. PNM Venture Syariah Makassar memiliki manfaat terbanyak sedangkan sisanya yang menyatakan kurang setuju dan tidak setuju 6 persen. Hal ini berarti bahwa sistem pembiayaan UMKMK pada PT.PNM Venture Syariah Makassar memiliki manfaat yang besar

\section{Prosedur pembiayaan Usaha Mikro, Kecil, Menengah, dan Koperasi (UMKMK).}

Manfaat prosedur pembiayaan Usaha Mikro, Kecil, Menengah, Dan Koperasi (UMKMK) Pada PT. PNM Venture Syariah Makassar. Di mana prosedur pembiayaan adalah rangkaian aktivitas (kegiatan) yang berurut dan tidak saling melampaui di dalam proses pemberian pembiayaan pada UMKMK yang menjadi nasabahnya.

Komposisi Persentasi responden berdasarkan dari 7 Item pertanyaan dari prosedur pembiayaan Usaha Mikro, Kecil, Menengah, dan Koperasi (UMKMK ) Pada PT. PNM Venture Syariah Makassar dapat dilihat pada tabel berikut:

Tabel 4.2. Distribusi Responden berdasarkan Prosedur pembiayaan

\begin{tabular}{|llll|}
\hline $\begin{array}{l}\text { No } \\
\text { Item }\end{array}$ & Tanggapan & $\begin{array}{l}\text { Jumlah } \\
\text { Responden }\end{array}$ & Persentase \\
\hline 1 & Tidak Setuju ( TS) & 2 & $4 \%$ \\
2 & Kurang Setuju ( KS) & 3 & $6 \%$ \\
3 & Cukup Setuju ( CS) & 2 & $4 \%$ \\
4 & Setuju ( S ) & 36 & $72 \%$ \\
5 & Sangat Setuju ( SS) & 7 & $14 \%$ \\
\hline Jumlah & & 50 & $100 \%$ \\
\hline
\end{tabular}

Sumber :data telah diolah

Berdasarkan tabel diatas menunjukkan jumlah nasabah UMKMK yang menyatakan prosedur pembiayaan UMKMK memiliki manfaat usaha pada PT.PNM Venture Syariah Makassar berdasarkan hasil tebar kuesioner kepada nasabah dapat dilihat bahwa sekitar 4 persen nasabah yang menyatakan tidak setuju jika prosedur pembiayaan UMKMK pada PT.PNM 
Venture Syariah Makassar memiliki manfaat, 3 persen yang menyatakan kurang setuju jika prosedur pembiayaan UMKM pada PT.PNM Venture Syariah Makassar memiliki manfaat, 2 persen yang menyatakan cukup setuju jika prosedur pembiayaan UMKMK pada PT.PNM Venture Syariah Makassar memiliki manfaat, 72 persen yang menyatakan setuju yang jika prosedur pembiayaan UMKMK pada PT.PNM Venture Syariah Makassar memiliki manfaat dan 14 persen yang menyatakan sangat setuju jika prosedur pembiayaan UMKMK pada PT.PNM Venture Syariah Makassar memiliki manfaat jadi dapat disimpulkan responden yang menyatakan setuju, cukup setuju dan sangat setuju sekitar 90 persen prosedur pembiayaan UMKMK pada PT. PNM Venture Syariah Makassar memiliki manfaat terbanyak sedangkan sisanya yang menyatakan kurang setuju dan tidak setuju sekitar 10 persen. Hal ini berarti bahwa prosedur pembiayaan UMKMK pada PT.PNM Venture Syariah Makassar memiliki manfaat yang besar bagi kelangsungan usaha nasabahnya.

\section{SIMPULAN}

Berdasarkan hasil penelitian yang telah dibahas sebelumnya, dan sebagai rangkaian dari penelitian ini maka dapat diuraikan kesimpulan sebagai berikut:

1. Sistem dan prosedur pemberian pembiayaan UMKM yang diterapkan pada PT. PNM Venture Syariah Makassar sudah sesuai dengan ketentuan Undang - Undang No.23 Tahun 1999 dan ketentuan OJK (Otoritas Jasa Keuangan), dimana PT.PNM Venture Syariah Makassar ditunjuk menjadi salah satu BUMN yang menjadi koordinator dalam menyalurkan dan mengelola 12 skim program pembiayaan.

2. Sistem Dan Prosedur pemberian pembiayaan terhadap UMKM memberikan Manfaat yang cukup besar terhadap kelangsungan usaha UMKM yang menjadi nasabahnya, karena sistem dan prosedur yang diterapkan tidak menyulitkan UMKM dalam mengajukan permohonan pengajuan pembiayaan.

\section{DAFTAR PUSTAKA}

Ali, Masyhud, 2004,Assed Liability Managemen, Cetakan Pertama, PT Elex Media Komputindo, Jakarta.

Antonio, Muhammad Syafi'I, 2003, Bank Syariah, Cetakan Ketujuh, PT Gema Insani Press, Jakarta.

Djinarto, Bambang, 2000 Banking Asset Liabilty Managemen, Ceteakan Pertama, PT Gramedia Pustaka Umum, Jakarta

Hasuban, Malayu, 2001 Dasar-dasar Perbankan Cetakan pertama, PT Bumi Aksara jakarta.

Irmayanto, Juli, 2004 Bank dan Lembaga Keuangan, Cetakan keempat, Universitas Trisakti, Jakarta.

Riyadi, Selamet, 2003.Banking Assets and liability Management, Fakultas EkonomiUniversitas Indonesia Jakarta.

Sugiyono. 2007. Metode Penelitian Bisnis: Bandung. Alfa Beta 
70|Ad'ministrare, Vol. 3 No. 2, 2016

Sugiyono. 2012. Metode Penelitian Kombinasi (Mixed Metode):Bandung.Alfabeta

Teguh, Muhammad, 2002.Metodologi Penelitian Ekonomi, Edisi Kedua, PT. RajaGrafindo Persada Jakarta.

Tjoekam, Moh, 1999.Perkreditan Bisnis Inti Bank Komersial, Cetakan PertamaPT. Grenmedia Pustaka Umum Jakarta

Undang-Undang No. 7 Tahun 1992 Tentang Perbankan sebagaimana telah diubah dengan undang-undang No. 10 Tahun 1998

Tambunan Tulus, 2012,Usaha mikro kecil dan menengah di Indonesia cetakan pertama, LP3ES, Jakarta

Tambunan Tulus, 2012,Manajemen Perbankan Cetakan pertama, LP3ES, Jakarta. 